ROCZNIKI HUMANISTYCZNE

Tom LXIX, zeszyt $12-2021$

DOI: https://doi.org/10.18290/rh216912-16

TETIANA MASKOVYCH

\title{
INSTRUMENTAL MUSIC AS AN ELEMENT OF EDUCATION IN THE CHILD'S INNER WORLD: EXAMPLE OF THE CHAMBER CANTATA A VIEW INTO THE CHILDHOOD BY HANNA HAVRYLETS
}

The article is dedicated to Hanna Havrylets' chamber cantata $A$ View into the Childhood, based on poems by Mykola Vingranovskyi, written for soprano and chamber orchestra. Each of the three parts of musical language of the cantata was thoroughly analyzed and characterized. The common intonations of leitmotif meaning were highlighted, as well as the uniqueness of end-to-end plot-image line and genre-stylistic unity.

Music, instrumental in particular, is an extremely important factor contributing to the education of children'perception and awareness; it perfectly shapes the inner aesthetic taste and individuality, develops imagination and world outlook. The child's attitude to musical art generally depends on the very first musical impressions and experiences, on the initial stage of musical education and training, because music can bring pleasure and provoke strong emotional feelings at the same time, opening the unknown world of children's fantasies. By applying the proper music, some emotional disorders, fears, uncontrolled behavior, communication difficulties are corrected; music helps to effectively free one from complexes and lack of confidence. The article seeks to describe

Dr Tetiana MASKOVyCH - Przykarpacki Uniwersytet Narodowy im. Wasyla Stefanyka w IwanoFrankiwsku; adres do korespondencji: ul. Szewczenki 57, 76108 Iwano-Frankiwsk [вул. Шевченка, 57, 76018 м. Івано-Франківськ], Ukraina; e-mail: tetiana.maskovych@pnu.edu.ua; ORCID: https:/orcid.org/ 0000-0003-4731-8350.

Dr TETIANA MASKOVYCH, Vasyl Stefanyk Precarpathian National University in Ivano-Frankivsk; address for correspondence: 57 Shevchenko St., 76018 Ivano-Frankivsk [вул. Шевченка, 57, 76018 м. Івано-Франківськ], Ukraine; e-mail: tetiana.maskovych@pnu.edu.ua; ORCID: https:/orcid.org/ 0000-0003-4731-8350. 
the stylistic features of the chamber cantata A View into the Childhood and methods of embodying the childhood theme with respect to pictorial analysis.

The only right way for any artist is delving into the native source. But what the artist finds in the folk treasury additionally requires skills for using works of folk culture. Discreditation is both an intrusive, inappropriate citation of primary sources and artificial stylization along with eclecticism. The national roots are just an impetus for personal creative imagination. Even avant-garde techniques may be combined with folklore themes in an interesting and fresh way, claims Hanna Havrylets. She is one of the brightest composers who give their creative works to children, but besides being a wonderful composer and an active public figure, she is first of all a mother and pedagogue. In her numerous compositions, the artist reveals the ideas of childhood, creates miniatures intended for children's perception and performance. These include in particular: chamber cantata $A$ View into the Childhood based on poems by Mykola Vingranovskyi for soprano and chamber orchestra (1987), pianoforte works for young pianists (1997), Let's Sow the Golden Stone - a musical stage performance for folk voice, boys' choir, symphony orchestra, instrumental groups and ballet (1997-1998) and Barbivska Carol - a choral folk concert of oratorical type (2010).

From an early age, Hanna Havrylets was learning from the unsurpassed master Vasyl Kufliuk, who had two diplomas: the University of Warsaw (as a mathematician) and the Warsaw Conservatory; he worked on the unique method of developing absolute musical hearing in children; in addition he had an exceptional pedagogical flair, did not neglect the importance of problems of children's musical education. Kufliuk instilled a fine sense of children's thinking in the mind of later composer, taught her the importance of developing inner world in kids and awareness of need in children's repertoire. The subsequent teachers of Hanna Oleksiyivna were Volodymyr Flys and Myroslav Skoryk, who contributed to her development as an author. "She is not trying to hide behind new trends. She is striving for 'pure' music, not cluttered with complicated musical language. Her direction of creativity is positive," Myroslav Skoryk said about his pupil in an interview.

The chamber cantata $A$ View into the Childhood was written by Hanna Havrylets at a quite young age (29). At that time, the composer, who was not yet widely known to the public, was immersed in pleasant, warm, family troubles of upbringing her little sonny Yurko (the son was only two years old), therefore the topic was very close to the children's world. The cantata is characterized by continuous search of her own writing style, because this work 
was one of the first pieces written after the graduation, thus at the onset of her independent creative path. In it one can hear a single mood, sounding in tune with the wonderful poems of Vingranovskyi, which immerse the listener in the "lacy world" of childhood memories. Each time the composer finds a new illumination of the poetic plot: pastel, carefree in the first part (Our hare fell asleep again in his dream); scherzo-whimsical in the second part (Cat, cat, golden tummy); sad, with a hint of anxiety and uncertainty in the last part (Geese have flown). The folklore, authorial, innovative source of melody, of course, is very noticeable. Already in this cantata we observe the trends which will characterize the composer's works in her more mature period: the embodiment of bright images related to the animal world being so close to children, referral to folklore genres, complication of musical language.

No wonder that Hanna Havrylets used the texts of a Ukrainian writer of the 1960s, Mykola Stepanovych Vingranovskyi (a poet, director, actor and screenwriter), as in 1984 he won the State Prize of Ukraine named after Taras Shevchenko for collections of works for children: Summer Morning, Summer Evening, Swallow at the Window, Good Night. Referring to a folk tale, the writer spiritualizes animals and birds with such an inspiration by skillfully endowing them with humor, that sometimes it seems: yes, perhaps, those creatures could really "think" or "say" in that way! And the theme of child's friendship with an animal or bird, so eternal for literature, has its own peculiarity in M. Vingranovskyi's works: the unity of the living world seems to recover in kids, for this feeling is lost in adults. The theme of child is not just a theme for the writer. His poems are meant for children and depict children, and perhaps, in his poems he is truly natural, because there he reaches the freedom of self-expression, which exists only in childhood and which is inevitably lost as time goes. His "children's" poems are fundamentally innovative, as they follow children's imagination, the poetics of childish soul. And they pour new light on the nature of whole poetry by Vingranovskyi as such, which contains the immediacy of world perception, gifted to people long ago in childhood, along with the paradoxicality of fantasy and purity of soul.

All the poems, chosen by Hanna Havrylets for her cantata, were written at different times and the artist did not combine them into a cycle, instead a complete scenario is built in their musical form. Among them: Our hare fell asleep again in his dream... (1969), Cat, cat... (1968), Geese have flown... (1964). The composer chose the chamber composition of orchestra for her work - the whole string section, high wooden wind instruments and bells were involved. The vocal part was transferred to the soprano part. 
The cantata consists of three parts, which are named according to the literary primary source. In part I, Our hare fell asleep again in his dream..., Havrylets uses the genre of lullaby - it is the most intimate song that a child hears from his mother's lips. Lullabies are associated with childhood memories, even the specific "smell of childhood", which will be carried by the child in memories for a lifetime. The author depicts the living nature as if through the prism of a dream: the images of Hare, Night, Dawn, Ant and Chamomile appear and become personified. Already from the introduction we can imagine the secret world of dreams, skillfully divided by the composer using musical means: repetition of one melodic phrase, restrained dynamics, pedal point, slumbrous seconds (characteristic feature of lullabies), secret and mysterious flute motifs, the sound of bells - all these are used by the composer to depict the condition of singing night songs and gradual falling asleep. This peculiar music seems to be putting our hero Bunny to sleep.

The beginning of the main section of the part is emphasized by the key change (A flat-major), tempo (Moderato) and stroke in the string group (Vibrato). The musical material of introduction contains three main intervals that form the intonation system of the whole part: second, fourth and fifth. Exactly this complex acquires the leitmotif significance, as the slumbrous oscillating motion, typical for the whole cantata, will sound in different versions. In the orchestral part, the composer seems to reproduce what is impossible to see, only to imagine. With the introduction of the vocal part, this is confirmed by the literary text: Our hare fell asleep again in his dream - every time the soloist's melodic phrases are interrupted by inlays of bells. Such stops bring calmness and slowness into the material flowing (as in lullabies) and add fabulous sounds due to their "silver" timbre. By contrast to instrumental parts, the vocal one immediately demonstrates a rather wide range (in the scope of small seventh interval) and smooth development of musical material, which adds the narrative character.

Such rather complicated harmonic means demonstrate the modern author's interpreting of classical principles: in the first couplet the composer uses mainly the string composition of orchestra, only occasionally supplemented by a short motif of wooden wind instruments (seemingly the most intimate character of the part content). The second couplet contrasts with the first by pitch axis (the minor is opposed to the major) - the composer uses polyphonic means, thus convincingly showing the thick darkness of the night, mentioned in the poetic lines. The image of the Star referred to in the text is accompanied by imitational performance of the soloist's last phrase with the first violins 
and flutes, this seems to depict the twinkling of stars in the night sky. The last "words" of the bells are giving a fabulous shade to the musical story.

Therefore, in the first part Hanna Havrylets skillfully reproduces the poetic text by the following musical means: harmonics - movement in parallel intervals, second complication of third harmonies, clusters, unexpected tonal comparisons; rhythmic - syncopes, melodious cradling motion; polyphonic - single imitations and melodic - a wide range of vocal parts. The musical language of the first part uses the folk genre of lullaby, combines the traditional means of musical expression with modern ones. The unity of the form is facilitated by saturation of musical canvas with the leitmotif sound and its variant conductions.

The second part of the cantata, Cat, Cat... is another (but different) example of image of lullaby genre. Here the author already introduces the elements of humorous children's songs-counters, and at the same time she applies twice as fast tempo. The active accords, sounding in all groups of instruments, depict the image of traditional Ukrainian lullaby character - the Cat, who quietly sneaks up on soft paws. The vocal part is quite extensive here, multiple repetitions continue the lullaby motif. With the development of musical canvas, the composer introduces a wave of timbre contrasts - violins and altos, which perform parallel fourth chords (the part started from them) on the piano, giving a touch of illusion to the sound, the feeling of approaching something from afar. With each new motif, the harmony is getting more and more complicated by sudden interruption and replacement by the new image of Sleep - sudden piano, trillo in low string instruments and the introduction of a new melody of circling type in the flute. While the image of Cat, who quarreled and did not let the child sleep, was depicted at the very beginning of work, in this part this Cat already dips into the "charms of the night" and sweetly falls asleep. Thus, in the second part the author preserves the previous motives and enriches the musical canvas with a wealth of features and their corresponding sonorous effects, uses a kind of melodic motion: pendulum-shaking, circling (as an element of cradling) and movement by parallel fifths. By using these means, Hanna Havrylets skillfully reflected the images of poetical text - the Cat (in particular, his moves), Mysterious Night and Mysterious Dream.

The third part, The Geese Have Flown ... (a continuous sequence of nonaccords) is a moment of brightly expressed musical immersion into a sweet dream, redounded by the musical material of the part. The brief introduction (string instruments) includes the thematic material, taken from the first part, still supplemented and decorated with "novelties": tremolo using mute, a sequence of non-accords, return to the slow tempo of initial sounds of the vocal 
part. It depicts directly what is happening in the dream, using the chanting of one syllable at the end of the phrase, which resembles vocalization, so typical for the lullaby genre - hu-u, tia-akh, bo-o; the syncopes and periodic metric changes create the illusion of volatility and uncertainty. It is worth noting that in the poetic text Vingranovskyi used the phrase "the geese began cackling", which is hard for kids to pronounce, therefore Hanna Oleksiyivna skillfully replaced it with the phrase "the geese began narrating" for better children's perception, which enables kids to understand the meaning of the text. In the next episode, the author uses the means of sound imitation by showing geese cackling. This point is the culmination of the whole part of the musical work. The last part of the cantata summarizes the concept of the whole musical work.

In conclusion, it is worth noting that in the chamber cantata the composer skillfully combines folklore traditions with the classical principles in a specific modern authorial interpretation. The complicated harmonic language dominates throughout the full cycle, it is aimed at sound imitation and certain authorial sonorous effects. The intonation accords are as close as possible to the genre requirements of the lullaby, whereas the whole cycle demonstrates skillful mastery of all means of orchestral and vocal writing.

\section{BIBLIOGRAPHY}

Afanasyev, Yuriy. "Sotsialne pryznachennya mystetstva yak system o utvoryuvalnyy chynnyk natsionalnoyi khudozhnoyi kultury." Kulturologichna dumka, no. 2, 2010, pp. 170-173 [Афанасьєв, Юрій. «Соціальне призначення мистецтва як систем о утворювальний чинник національної художньої культури». Культурологічна думка, № 2, 2010. сс. 170-173].

Bench-Shokalo, Olga. Aktualizatsiya zvychayevoyi tradytsiyi v suchasniy muzychniy kulturi Ukrayiny (kompozytorska tvorchist, vykonavstvo, suspilni formy buttya). Kyyiv, 2008. PhD dissertation [Бенч-Шокало, Ольга. Актуалізація звичаєвої традииії в сучасній музичній культурі України (композиторська творчість, виконавство, суспільні форми буття). Київ, 2008. Диссертация на степен доктора].

Kostyuk, Natalia. "Eskiz do kharakterystyky (aspekty sakralnoho u muzytsi Hanny Havrylets)." Studiyi mystetstvoznavchi, no. 2, 2004, ss. 82-93 [Костюк, Наталія. «Ескіз до характеристики (аспекти сакрального у музиці Ганни Гаврилець)». Студії мистецтвознавчі, № 2, 2004, сc. 82-93].

Toropova, Alla. Fenomen muzykalnogosoznaniya: metodologiyai ssledovaniya i razvitiye. Moscow, 2009. $\mathrm{PhD}$ dissertation [Торопова, Алла. Феномен музыкальногосознания: методологияи сследования и развитие. Москва, 2009. Диссертация на степен доктора].

Shelyuto, V. "Problema sakralnogo yak svitoglyadna." Nauka. Religiya. Suspilstvo, no. 4, 2010, ss. 94-101 [Шелюто, В. «Проблема сакрального як світоглядна». Наука. Релігія. Суспільство, № 4, 2010, cc. 94-101]. 